\title{
Prospects of Implementation of the UN SDG in Russia ${ }^{1}$
}

\author{
O. Kolmar, A. Sakharov
}

Olga Kolmar - Researcher, Centre for International Institutions Research, Russian Presidential Academy of National Economy and Public Administration; 11 Prechistenskaya naberezhnaya, 119034, Moscow, Russian Federation; E-mail: kolmar-oi@ranepa.ru

Andrei Sakharov - Researcher, Centre for International Institutions Research, Russian Presidential Academy of National Economy and Public Administration; 11 Prechistenskaya naberezhnaya, 119034, Moscow, Russian Federation; E-mail: sakharov-ag@ranepa.ru

\begin{abstract}
The Sustainable Development Goals, adopted by the UN General Assembly on 25 September 2015 in Resolution 70/1 "Transforming our world: the 2030 Agenda for Sustainable Development" embrace a wide range of issues facing both developed and developing countries.

Implementation of the SDG is of particular interest both in international context and according to the agenda of socio-economic development of the Russian Federation, thus the task of identifying medium-term sustainable development priorities of Russia acquires great importance. The paper is based on comparative analysis of priorities of the Presidential Order "On National Goals and Strategic Objectives of the Russian Federation through to 2024" (the May-2018 Executive Order), active state programs and the SDG targets. The purpose of the paper is to determine the correlation between the SDG targets and Russia's medium-and long-term national strategic goals.

The outcomes of the research demonstrate that there is a room for further increase of effectiveness of implementation of the SDG based on contingent approach ensuring solidarity and balancing of social, economic and ecological aspects of the SDG implementation. Russia's strategy towards implementation of the $S D G$ requires greater level of contingency meaning incorporation of social aspects of sustainable development into national strategic documents.
\end{abstract}

Key words: Sustainable Development Goals (the SDG); sustainable development; Agenda 2030; socioeconomic development of the Russian Federation; May-2018 Executive Order; State programs of the Russian Federation

For citation: Kolmar O., Sakharov A. (2019) Prospects of Implementation of the UN SDG in Russia. International Organisations Research Journal, vol. 14, no 1, pp. 189-206 (in English). DOI: 10.17323/19967845-2019-01-11

${ }^{1}$ The editorial board received the article in September 2018.

The research was carried out within the framework of the RANEPA research project "Leading Donors' Sustainable Development Goals Implementation Strategies. Main results". 


\section{Introduction}

During the 2015 session of the United Nations General Assembly (UN GA) 193 countries adopted Resolution 70/1, "Transforming Our World: The 2030 Agenda for Sustainable Development" (hereafter, Agenda 2030), which laid down the sustainable development goals (SDGs) for the next 15 years [UN, 2015]. There are 17 goals and 169 indicators detailed in Agenda 2030 aimed at maintaining a balance of the economic, social and environmental aspects of development for the international community in the long run.

The implementation of the SDGs is a topic of particular interest both in the international context and in terms of the Russian Federation's agenda of socio-economic development. Russia actively participated in formulation of the UN's sustainable development agenda while pursuing its own priorities, namely promoting sustainable industrial development, traffic security, the spread of healthier lifestyles, combating non-communicable diseases, ensuring reliable access to basic energy services, transportation, education, healthcare and social security.

This article analyzes the incorporation of the UN SDGs within the socio-economic development policy of the Russian Federation, as laid out particularly in the decree "On National Goals and Strategic Objectives of the Russian Federation through to 2024" (hereafter, the May 2018 Executive Order) [President of Russia, 2018a] and in the ongoing state programmes of the Russian Federation [Government of the Russian Federation, 2010]. This acquires a particular urgency due to the preparation of a voluntary report to the High-Level Political Forum on Sustainable Development on the Russian Federation's progress toward the implementation of the SDGs, planned for 2020. To this end, content analysis of national and international documents and comparative methods of study were used. The results of the comparative examination of Russia's strategic priorities of socio-economic development stipulated in the May 2018 Executive Order and measures under government-sanctioned programmes were summarized in a concluding table available on the Centre for International Institutions Research at the Russian Presidential Academy of National Economy and Public Administration (CIIR RANEPA) website [RANEPA, c. a.]. It is should be noted that this article does not evaluate the effectiveness of current or planned measures within the framework of Russia's sustainable development policy. The purpose of the article is to determine the correlation between the SDG targets and Russia's medium- and long-term national strategic goals. The article specifically focuses on domestic aspects of SDG implementation, while issues related to the promotion of international development are excluded from analysis. Because SDG 17 (partnership for the goals) does not touch upon any aspect of the national development agenda, it is also excluded.

Several recently published articles touch upon the process of the realization of the SDGs in Russia on various aspects. Early research on this topic was conducted by the Analytical Centre for the Government of the Russian Federation in 2016. The outcomes were presented in an analytical report entitled "Sustainable Development Goals and Russia" [Bobylev, Grigoryev, 2016]. The Centre continued its work on human de- 
velopment in the Russian Federation and produced two additional reports - "Ecological Priorities for Russia" (2017) and "Human and Innovations" (2018) [Analytical report, 2017; Analytical report, 2018].

S.N. Bobylev and S.V. Solovyova [2017] published an article on the measures of adaptation and realization of the SDGs in Russia; L.M. Grigoryev and V.A. Pavlushina presented an article on inequality as a development issue [2017]. N.E. Ryazanova focused on integration of the SDGs into vocational training curricula [2018]. Corporate responsibility in the implementation of the SDGs was examined by L.G. Sudas [2017] and O.I. Dunaev and V.A. Nagornov [2017]. However, research comparing Russia's mid- and long-term policies with the SDG targets has not yet been presented.

\section{Measures for the Realization of the SDGs in Russia}

In March 2016, the Federal Council of the Federal Assembly of the Russian Federation promulgated proposals for the parliamentary hearings on the post-2015 UN agenda [2016]. The recommendations focused on issues related to international development assistance and national efforts on adaptation to climate change. The document also included important recommendations on the spread of information concerning Russia's activity as a global donor.

The coordination of efforts among various governmental bodies concerning the SDGs is formally conducted by the interagency taskforce for the Executive Office of the President of the Russian Federation on issues related to climate change and sustainable development. In 2016 the taskforce examined the conformity of the tasks and goals laid out in Russia's executive orders issued in 2006-2016 with the SDGs, in close cooperation with federal executive bodies. The taskforce inspected the status of statistical data necessary for monitoring implementation of the SDGs in Russia and established a new expert group on info-statistical support for the monitoring of SDG implementation, composed of officials from federal executive bodies.

Despite the fact that three years have passed since the adoption of the SDGs, Russia has not laid out a national approach to their implementation and has not formulated an adapted national strategy of sustainable development. However, the Russian Statistical Service (Rosstat) has started to prepare a set of indicators to monitor SDG implementation and in September 2017 the Federal Plan for Statistical Efforts was complemented with indicators of SDG implementation in Russia. Ninety indicators were incorporated with the majority focusing on such aspects as poverty and welfare, decent jobs and economic growth, healthcare and education. Russia also actively participates in work of the UN Conference of European Statisticians on issues related to SDG statistics.

The official representatives of Russia responsible for the country's activities toward the implementation of the SDGs on national and international levels have announced several times Russia's intention to introduce national and subnational SDG indicators, and to establish an accounting platform for delivering information to the UN and prepar- 
ing national reports containing Russia's achievements in SDG implementation on a regular basis. Recently, steps were taken toward establishing a national system of indicators for measuring the progress achieved in this sphere. Concluding and presenting Russia's voluntary report to the UN High-Level Political Forum on Sustainable Development could be a great impetus for these efforts. Despite the fact that 162 countries (46 in 2018) including several Eurasian Economic Union countries - Belarus (2017), Armenia (2018), Kazakhstan (2019) - and two BRICS members - China (2016) and India (2017) - have already presented their achievements, Russia has not yet completed its report to the UN High-Level Political Forum. The outcomes of the evaluation of SDG implementation in Russia conducted by the Analytical Center [Bobylev, Grigoryev, 2016] generally match the SDG Index demonstrating countries' achievements in the implementation of the SDGs [Sachs, Schmidt-Traub, Kroll, Durand-Delacre, and Teksoz, 2017] arranged by the Sustainable Development Solutions Network [SDSN, c. a.].

Russian and foreign experts have noted that since the 2000s Russia has achieved the most significant results in combating hunger (SDG 2) and poverty (SDG 1), and has demonstrated moderate accomplishments in providing quality education (SDG 4), promoting modern and clean sources of energy (SDG 7), employment policy (SDG 8), building sustainable cities and communities (SDG 11) and mitigating the effects of climate change (SDG 13). There is more to be done concerning gender equality (SDG 5), clean water and sanitation (SDG 6), sustainable infrastructure (SDG 9), sustainable consumption and production (SDG 12), building partnerships between governments, civil society organizations and the private sector (SDG 17), as well as preservation of life on surface and water ecosystems (SDGs 14 and 15).

The most challenging SDGs for Russia are good health and well-being (SDG 3), peace, justice and strong institutions (SDG 16) and inequalities (SDG 10). Economic development based on a raw-export model increases the environmental impacts that cripple people's health and well-being.

According to the abovementioned report on sustainable development goals and Russia [Bobylev, Grigoryev, 2016], strategic documents of Russia, including those adopted in 2017 - the Strategy on Economic Security and the Strategy on Ecological Security - do not correlate with the sustainability principles and thus extra measures for the implementation of the SDGs into Russia's agenda are required.

The key medium-term strategic document of Russia is the "Action Plan of the Government of the Russian Federation Through 2024" [Government of the Russian Federation, 2018a] $]^{2}$ adopted in September 2018.

The Russian Federation has not yet adopted a document on the implementation of the SDGs in line with the General Assembly resolution adopted in 2015. The majority of SDG targets are realized by means of national socio-economic development policy

${ }^{2}$ The Action Plan is based on the Presidential Address to the Federal Assembly of the Russian Federation [President of Russia, 2018b], the May 2018 Executive Order [President of Russia, 2018a], Strategy of National Security of the Russian Federation and Forecast of social and economic development of the Russian Federation till 2024 [Government of the Russian Federation, 2018a]. 
[Government of the Russian Federation, 2010] including subprogrammes and specialpurpose programmes [State Programme of the Russian Federation, c. a.].

Applicability of the implementation of the SDGs in Russia was fixed in the Presidential Address to the Federal Assembly in 2018 [President of Russia, 2018b] and the May 2018 Executive Order [President of Russia, 2018a]. The tasks formulated in these documents touch upon various issues - healthcare, education, demography, commodities and urban areas, international cooperation and export, labour productivity, SMEs and promotion of private entrepreneurship, safe and quality infrastructure, ecology and digital economy - all of which correlate with the SDGs and thus should be incorporated into strategic plans.

The May 2018 Executive Order is a programme document that establishes the goal of achieving a scientific and socio-economic breakthrough. The milestones of this breakthrough are the achievement of: Russia as one of the top-five economies of the world; population growth; increased life expectancy (from 72 to 78 years and up to 80 by 2030); growth of disposable income of the population and double-time decrease of poverty; annual improvement of living conditions for five million households; and a healthy environment for self-realization and creativity of every individual.

The milestones listed above are to be achieved by 2024 by means of national policies in 12 spheres of strategic development [Government of the Russian Federation, 2018a]: demography; healthcare system development (SDG 3); education (SDG 4); housing and urban areas (SDG 11); ecology (SDGs 13, 14 and 15); safe and quality automobile roads (SDG 9); improving labour efficiency and employment (SDGs 8 and 9); culture (SDGs 4, 8 and 9); promotion of SMEs and private entrepreneurship (SDGs 2, 3, 8 and 9); international cooperation and export. Some of the projects are based on programmes launched in 2016 in such spheres as healthcare, education and housing; in other cases, a programme was put in place (digital economy).

A new national project management system was introduced in order to implement the policies. Project authorities are formed on basis of the government and the federal executive bodies [President of Russia, 2018a]. Some bottlenecks may arise related to the nuances of coordinating the projects discussed above with existing programmes that had been a cornerstone of budgeting before 2018. Preparation of national and federal projects should take into account their contribution to the implementation of the May 2018 Executive Order's goals and correlate with existing state policies.

\section{The Inclusion of UN SDGs into Russia's State Programmes and the May 2018 Executive Order}

\section{SDG 1: End Poverty in All Its Forms Everywhere}

Two objectives concerning double-time reduction in poverty indicators by 2024 and securing growth of real household earnings were introduced in the Presidential Address to the Federal Assembly and the May 2018 Executive Order (SDG 1.2). Con- 
cerning social security (SDG 1.3) further increase of pension scales and their regular indexation above inflation rates is planned as well as improvement in the quality of healthcare and social services for seniors.

Several programmes related SDG 1 priorities are currently in effect: "Employment of Population," "Social Support," "Comfortable and Affordable Housing for the Citizens of the Russian Federation."

Measures provided in the listed programmes generally correlate with SDG 1 targets 1.1, 1.2, 1.3 and 1.a. At the same time, a few targets are not covered by the programmes, in particular, target 1.4 concerning ownership and control over land and other forms of property and access of the poor to "natural resources, appropriate new technology and financial services, including microfinance;" target 1.5 "build the resilience of the poor and those in vulnerable situations and reduce their exposure and vulnerability to climate-related extreme events and other economic, social and environmental shocks and disasters;" and target 1.b "create sound policy frameworks at the national, regional and international levels, based on pro-poor and gender-sensitive development strategies, to support accelerated investment in poverty eradication actions."

\section{SDG 2. Zero Hunger}

Despite some particular economic and social discrepancies, fighting hunger (SDGs 2.1 and 2.2) is not included in the list of Russia's national priorities. Food security is skirted in the text of the May 2018 Executive Order. However, some priorities in agriculture were set, for example, establishment of a support system for farmers and promotion of rural cooperation, fostering export potential and competitive advantages.

In 2013 the state programme for agricultural development and regulation of agricultural products, raw materials and commodities market for 2013-2020 was launched. Initiatives under this programme relate to the following targets of SDG 2: target 2.3 (increase agricultural productivity), target 2.4 (ensure sustainable food production systems), target 2.5 (maintain the genetic diversity of seeds and cultivated plants), target 2.a (increase rural investment) and target 2.c (ensure the proper functioning of food commodity markets).

Implementation of target 2.a (correct and prevent trade restrictions and distortions in world agricultural markets, including through the parallel elimination of all forms of agricultural export subsidies and all export measures with equivalent effect) is facing challenges due to competitive weakness of the local commodities suppliers and the current sanction and counter-sanction regimes imposed on Russia by many countries of the world.

\section{SDG 3. Ensure Healthy Lives and Promote Well-Being for All at All Ages}

Healthcare system development was widely discussed among other topics in the May 2018 Executive Order. The order prioritized an increase in financing initiatives 
aimed at fostering the well-being of mothers and infants (no less than 3.4 trillion roubles by 2024), improvement of access to and quality of medical care, spread of medical and obstetric centres and outpatient clinics across the country. Moreover, it was pointed out in the Presidential Address to the Federal Assembly that healthcare expenses should account for no less than $4 \%$ of gross domestic product (GDP) on average from 2019 to 2024.

Current measures provided under the state programme "Healthcare Development," initiated in December 2017, cover all the targets of SDG 3: subprogramme 4 "Protection of Mother and Child Health" (SDGs 3.1 and 3.7); subprogramme 1 "Diseases Prevention and Promotion of Healthier Lifestyle. Development of Emergency Care" (SDGs 3.2, 3.3, 3.4, 3.5, 3.a and 3.d); subprogramme 2 "Improvement of Specialized, Including High-End Aid" (SDG 3.6); subprogramme 9 "Expertise and Oversight in Healthcare;" subprogramme 3 "Development and Integration of Innovative Methods of Diagnostic, Prevention and Treatment, and Personalized Medicine" (SDGs 3.b and 3.c.).

\section{SDG 4. Quality Education}

Education development is mentioned among other priorities of the May 2018 Executive Order. In this sphere, the government of Russia is obliged to increase competitiveness of Russian education so that Russia achieves one of the top positions in the world in terms of quality of educational services. The Presidential Address to the Federal Assembly and the May 2018 Executive Order set out tasks in the sphere of education - improve access to elementary education (increase kindergarden capacity by 270,000 within a period of three years; 50 billion roubles of funding allocation); modernization of the system of vocational training, "promotion of professional staff in municipal authorities and civil service, private entrepreneurship and production;" 1 billion roubles of funding allocation in 2018 for the purpose of career-guidance for school students; "establishment of a system for continuing education for employees for the purpose of further improvement of knowledge and skills including digital skills;" and "establishment of a national system for professional development of teaching employees."

It is should be noted that the SDG 4 targets are mostly integrated into Russia's 2024 development agenda and current state policies. Under the framework of the programme "Development of Education" for 2013-2020 the following subprogrammes are in place: subprogramme 1 "Realization of Vocational Education Programs" (SDGs 4.3, 4.4, 4.5, 4.6, 4.b and 4.c); subprogramme 2 "Promoting Development of Pre-Elementary and Elementary Education" (SDGs 4.1, 4.2, 4.5, 4.a and 4.c); subprogramme 4 "Development of Supplementary Education and Realization of Youth Policy Initiatives" (SDG 4.5); subprogramme 5 "Improvement of Education Management System" (SDGs 4.b and 4.c).

SDG 4.7, focusing on ensuring that "all learners acquire the knowledge and skills needed to promote sustainable development, including, among others, through ed- 
ucation for sustainable development and sustainable lifestyles, human rights, gender equality, promotion of a culture of peace and non-violence, global citizenship and appreciation of cultural diversity and of culture's contribution to sustainable development," is an exception - current plans and policies of the government of Russia do not involve any actions to this end.

\section{SDG 5. Achieve Gender Equality and Empower All Women and Girls}

Generally, gender issues are lacking in Russia's programme and strategic documents. Russia's 2024 development agenda includes provisions concerning maternal health (SDG 5.6, sexual and reproductive health) and creating "conditions for professional careers of women with children" (SDG 5.1, end all forms of discrimination against all women and girls; SDG 5.c, promotion of gender equality and the empowerment of all women and girls at all levels).

It is should be noted that in 2017 Russia ranked 53rd out of 189 according to the UN Gender Inequality Index. Additionally, Russia lags behind the Organisation for Economic Co-operation and Development (OECD) countries in terms of deaths per 1000 births and teenage pregnancy. The most challenging issue is women's involvement in political processes measured according to the share of parliament mandates held by women - in these terms, Russia falls behind not only developed, but also the majority of developing countries, including the former Soviet Union [UNDP, 2017].

\section{SDG 6. Ensure Access to Water and Sanitation for All}

Within the framework of the May 2018 Executive Order several measures aimed at ensuring environmental resilience of water-related facilities of the Russian Federation are anticipated. These measures include: "ecological restoration of water facilities including a project aimed at a threefold reduction in the polluted sewage water flow that disembogues into the Volga river, sustainable functioning of the water resources utilization system of the Lower Volga and preservation of the ecosystem of the VolgaAkhtuba floodplain," and "preservation of unique water objects including realization of the project to preserve Lake Baikal, and removal of litter from the offshore strip and shore front of Lake Baikal, Lake Teletskoye, Ladoga Lake, Lake Onega and the Volga river, the Don, the $\mathrm{Ob}$ river, the Yenisey river, the Amur river, the Ural river and the Pechora river." Despite the fact that these steps lack a systematic approach and are project-based, they partly match SDG 6.3 (improve water quality by reducing pollution) and 6.6 (protect and restore water-related ecosystems).

Concerning sanitation, the May 2018 Executive Order includes special provisions to increase of quality of drinking water for the population, including community dwellers that are not connected to modern district water networks (SDGs 6.1 and 6.2).

The governmental programme "Recreation and Utilization of Natural Resources" (2013) includes subprogramme 2 "Utilization of Water Resources." Within the frame- 
work of this subprogramme such steps as "planning of water management and water protection practices, ensuring safe exploitation of hydro-technical utilities and IT support," "realization of flood prevention measures, minor repairs of hydro-technical utilities and measures to increase conveying capacity of rivers; informational and technical support; securing facilities run by RosHydroResources and reduction of amortization of hydro-technical facilities" are planned.

In addition, the government announced plans aimed at ensuring effective realization of state functions in water matters by means of "ensuring fulfilment of socioeconomic needs for water resources; prevention and mitigation of risks of floods and other harmful impacts of water; securitization of water utilization systems and hydrotechnical utilities; exercise of powers of regional authorities of the Russian Federation in the sphere of water policy." Generally, these steps suit SDG 6.4 (increase water-use efficiency across all sectors) and SDG 6.5 (integrated water resources management at all levels).

An important task that does not correspond with the Russian government's plans is SDG 6.b (support and strengthen the participation of local communities in improving water and sanitation management). Transparency and accountability ensured by direct involvement of stakeholders in formulation of policies are inherent in the SDGs. However, practices of this kind are not widely spread in the case of Russia.

\section{SDG 7. Affordable and Clean Energy}

The targets of SDG 7 are mostly incorporated into the May 2018 Executive Order. Among other priorities of the 2024 development agenda the following tasks were mentioned: development of energy infrastructure, guaranteed "provision of affordable electricity by means of electrification of the transportation corridors "West-East" and "North-South," including the Baikal-Amur Mainline and the Trans-Siberian Railway in conjunction with development of transport infrastructure; development of central power supply grids, including modernization of generation capacities of heat power plants, nuclear power plants and hydro power plants in accordance with demands of socio-economic development; sustainable energy supply in all regions of the Russian Federation... ; development of distributed generation, based, among other sources, on renewable sources of energy, in remote and isolated energy areas; incorporation of intellectual power facilities control systems based on digital technologies.”

The list of pre-planned actions corresponds with SDG 7.1 (ensure universal access to affordable, reliable and modern energy services), SDG 7.2 (renewable energy) and SDG 7.3 (energy efficiency). Target 7.b (expand infrastructure and upgrade technology for supplying modern and sustainable energy services) is also covered by Russia's development agenda except for the international component (support of least developed countries).

From a strategic point of view, SDG 7 is well represented in Russia's 2024 development agenda. 


\section{SDG 8. Promote Inclusive and Sustainable Economic Growth, Employment and Decent Work for AII}

It is obvious that economic growth and employment are essential for any national government, including Russia. The Presidential Address to the Federal Assembly and the May 2018 Executive Order establish several ambitious goals in this sphere: in the medium-term Russia must achieve a position among the top-five global economies with an economic growth rate exceeding the global average level amid stable macroeconomic indicators including an inflation rate of less than 4\% per year. By 2025 Russia's GDP should grow 1.5 times with annual growth rate about $3.7-3.8 \%$. The state programme "Economic Development and Economy of Innovations" focuses on the same objectives, providing complex measures - from an increase of investment attractiveness and improvement of corporate governance to promotion of market competitiveness and development of special economic zones. The abovementioned measures generally correspond with SDG 8.1 (sustain per capita economic growth in accordance with national circumstances).

Concerning growth of economic productivity of (SDG 8.2) and promotion of industrial activities, employment, entrepreneurship, creativity and innovations (SDGs 8.3, 8.5 and 8.6), the Presidential Address to the Federal Assembly and the May 2018 Executive Orders set the following goals: "increase labour productivity based on a new technological, managerial and human resources foundation;" doubling the amount of "non-resource export up to $\$ 250$ billion;" growth of labour productivity in middleand large-scale enterprises of primary non-resource sectors by $5 \%$ annually; promote involvement of no less than 10,000 middle- and large-scale enterprises of primary nonresource sectors into the process of implementing measures aimed at increased productivity; promotion of incorporation of state-of-the-art managerial, organizational and technological solutions to improve productivity and modernize sustaining capital also by means of tax preferences; removal of administrative and legislative barriers that compromise the growth of labour productivity and renovation of out-of-date and unproductive workplaces; introduction of methodological and organizational systems for promotion of growth of labour productivity in places; introduction of a human resource development system focusing on teaching the essentials of growing productivity of labour.

Support of micro- and small-size enterprises (SDG 8.3) is also included in the plans of the Russian government. The May 2018 Executive Order provides measures aimed at supporting first-time entrepreneurs and creating a framework to facilitate entrepreneur activity as well as easing of regulations and the tax burden for innovative micro- and small-size enterprises and self-employed people. According to the plan, by 2024 the number of micro- and small-size entrepreneurs including the self-employed would grow up to 25 million people.

The May 2018 Executive Order also provides policies to increase resource utilization efficiency (SDG 8.4). Specifically, the government plans to: effectively utilize land 
for large-scale housebuilding, effective production and consumption waste management; decrease the level of air pollution in large industrial centers; and ecologically restore water objects. An important aspect provided in the May 2018 Executive Order corresponds with SDG principles of transparency, openness and realization of civil society's initiatives: the "creation and effective functioning of public control system aimed at exposure and liquidation of non-authorized waste deposits in all regions of the Russian Federation."

Issues concerning facilitation of tourism (SDG 8.9) are also addressed in Russia's 2024 development agenda. The May 2018 Executive Order provides for the formulation of a national project on environmental matters with the purpose of developing ecotourism in national parks.

\section{SDG 9. Build Resilient Infrastructure, Promote Sustainable Industrialization and Foster Innovation}

Infrastructure development is one of the pillars of Russia's 2024 development agenda. This issue entrenches all other sectors including transport, energy, urban areas, education, healthcare and innovations. Specific attention is given to: preparation of a complex plan for modernization and extension of the country's backbone infrastructure; doubling expenditure on the spatial development of Russia's cities and communities by 2024; assigning more than 11 trillion roubles for the renovation of regional and local roadways; increasing the carrying capacity of the Baikal-Amur Mainline and the Trans-Siberian Railway up to 180 million tonnes by 2024; a tenfold increase of carrying capacity of the Northern Sea Route by 2025; facilitation of modern infrastructure ensuring safe treatment of hazardous waste of classes I and II and liquidation of the most dangerous objects of accumulated environmental damage; and building modern healthcare infrastructure.

In addition to hard infrastructure, digital and innovative infrastructure is also on the spot. The May 2018 Executive Order contains special prescriptions concerning the building of frontier innovative and scientific infrastructure; facilitation of "resilient and safe IT-infrastructure for high-speed transmission, processing and storage of big data open for all organizations and households;" "establishment of global competitive infrastructure for transmission, processing and storage of data mostly based on Russian technologies;" "creation of a system for acceleration of small- and middle-size enterprises including self-employed, and support infrastructure and services.”

\section{SDG 10. Reduce Inequality Within and Among Countries}

In Russian strategic documents the problem of inequality is dealt with by means of development of the system of social protection, and thus steps and measures mentioned in relation to SDGs 1 and 5 correspond with SDG 10. In the Presidential Address to the Federal Assembly 2018 the president highlighted the task of preparing a special pro- 
gramme of systematic support to increase the quality of life of seniors. Moreover, one of the pillars of the May 2018 Executive Order is provision of universal accessibility of social benefits for the population: "ensuring optimal accessibility of immediate medical services for the population (including remote settlements dwellers);" "building of modern and safe digital frameworks for high quality education of all grades and kinds;" "provision of affordable housing for middle-income households;" and guaranteed provision of affordable electricity.

However, gender and sociopolitical aspects of SDG 10.3 (ensure equal opportunity and reduce inequalities of outcome, including by eliminating discriminatory laws, policies and practices and promoting appropriate legislation, policies and action in this regard) are missed in the abovementioned documents.

\section{SDG 11. Make Cities Inclusive, Safe, Resilient and Sustainable}

As was mentioned above, Russia's 2024 development agenda pays great attention to development of urban areas. One of the top-priority national projects planned for implementation of the May 2018 Executive Order is the "Housing and Urban Areas" programme. According to the May 2018 Executive Order the milestones of the project are: "provision of affordable housing for middle-income households including opening up opportunities for purchasing (building) of housing by means of mortgage services with rate of interest lower than $8 \%$; expansion of residential development up to no less than 120 million square meters annually; substantial improvement of quality of urban areas, increase of the urban areas quality index by $30 \%$, double-time reduction in the number of cities with adverse environments in accordance to this index; facilitation of the mechanism of direct involvement of the population in creation of a comfortable urban environment, increase of the share of residents participating in urban development decision-making by $30 \%$; provision of persistent reduction of un-tenantable housing facilities."

According to the May 2018 Executive Order, targets 11.6, 11.7 and 11.a of SDG 11 are implemented apart from urban development plans and fall within the programme "Ecology" that indicates the absence of complex and systematic approach to facilitation of sustainable development in the Russian Federation.

\section{SDG 12. Ensure Sustainable Consumption and Production Patterns}

The May 2018 Executive Order provides the following measures for transition to more rational models of consumption and production: "effective consumption and production waste management including liquidation of all non-authorized waste deposits exposed by January 1, 2018 within cities' limits; significant reduction of air pollution in large industrial centres, including reduction of the total amount of air pollutants emissions by $20 \%$ in the most polluted cities;" "facilitation of the complex system for household waste management including liquidation and remediation of waste deposits, 
creation of a framework for recycling production and consumption waste forbidden to be buried; facilitation and effective utilization of systems of public control over exposition and liquidation of non-authorized waste deposits in all regions of the Russian Federation."

Measures within the framework of the programme "Protection of Environment," in particular, matching the SDG 12 targets, are provided by subprogrammes 1 ("Regulation of Quality of Environment"), 3 ("Hydrometeorology and Environmental Monitoring") and 8 ("Liquidation of Accumulated Ecological Damage") and by the priority project "Clean Country."

\section{SDG 13. Take Urgent Actions to Combat Climate Change and its Impacts}

As mentioned earlier, the May 2018 Executive Order provides several measures concerning environmental issues, and reduction of pollutants emissions in large industrial cities in particular. However, the document does not include risks and dangers caused by climate change and its implications for the territory of Russia.

Among active initiatives on environmental adaptation, the programme "Protection of Environment" for 2012-2020 could be mentioned. The programme provides: monitoring of subsurface states in relation to hazardous exogenous geological processes; "drafting of regulations providing effective functioning of rate setting of negative ecological footprint; planning of measures for the provision of economic incentives for the reduction of negative anthropological and technological environmental impacts; research aimed at increasing the quality of the environment and provision of environmental safety including scientific support of state policy in the sphere of mitigation of negative impacts on the atmosphere;" and also fulfilment of international environmental protection obligations.

\section{SDG 14. Conserve and Sustainably Use the Oceans, Seas and Marine Resources}

In Russia's 2024 development agenda there are no measures concerning the facilitation of environmental sustainability of maritime resources. Moreover, the goal to increase the traffic flow of the Northern Sea Route up to 80 million tonnes creates environmental risks in the vulnerable Arctic region.

However, within the framework of the active programme "Development of Fisheries Industry" several planned measures correspond with SDG 14.4 (effectively regulate harvesting and end overfishing, illegal, unreported and unregulated fishing), 14.5 (conserve at least $10 \%$ of coastal and marine areas, consistent with national and international law and based on the best available scientific information) and 14.6 (prohibit certain forms of fisheries subsidies). The programme provides further improvement of measures aimed at prevention, mitigation and liquidation of illegal, incommunicable and uncontrollable fisheries, provision of state monitoring on fisheries and preserva- 
tion of living marine resources, development of fisheries in areas under international treaties of the Russian Federation and preservation of living marine resources in the open part of the oceans, and drafting of regulations on quotas on harvesting of living marine resources imposed on Russian legal entities and self-employed persons within Russia's domestic waters.

\section{SDG 15. Sustainably Manage Forests, Combat Desertification, Halt and Reverse Land Degradation, Halt Biodiversity Loss}

In the May 2018 Executive Order, there are measures that correspond with SDG 15: "preservation of biodiversity including extension of specially protected natural sites by 5 million hectares, reintroduction of endangered species, building of infrastructure for ecotourism in national parks and preservation of forests by means of reintegration of logged or failed forest territories;" "utilization of systems of ecological regulation based on best available technologies by all facilities adversely affecting environment;" "preservation of biodiversity by means of creating no less than 24 new specially protected natural sites."

SDG 15.6 (fair sharing of the benefits arising from the utilization of genetic resources), 15.8 (prevent the introduction and significantly reduce the impact of invasive alien species) and 15.c (combat poaching and trafficking of protected species) are not covered.

\section{SDG 16. Promote Just, Peaceful and Inclusive Societies}

SDG 16 is barely addressed by the measures introduced in the May 2018 Executive Order, but target 16.6 (develop effective, accountable and transparent institutions at all levels) is indirectly covered. The government is working on incorporation of the system of digital civilian workflow based on digital technologies.

Corruption (SDG 16.5), violence and related deaths (SDG 16.1) and the rule of law (SDG 16.3) - issues that are crucially important for the development of the country - are not included in the list of priorities.

\section{Conclusion}

The majority of UN SDGs are fully or almost completely incorporated into Russia's 2024 development agenda. However, it should be noted that Russia's approach to implementing the SDGs requires more consistency. An important feature of the UN SDGs is their comprehensiveness requiring implementation of SDGs with due regard to their strong correlations. In this case, measures aimed at better provision of access to energy resources cannot be regarded as corresponding with the SDGs if they contravene the tasks concerning ecological sustainability. 
One aspect of the SDGs that is not fully incorporated into Russia's strategic documents is social justice and the promotion of human rights including gender inequality, development and representation of local communities, and building just, peaceful and inclusive societies. This is partly due to the fact that the Russian authorities do not consider these aspects to be priorities in terms of economic growth as a top mediumterm objective. Besides, the majority of the abovementioned issues manifest more on the practical implementation level, rather than during strategic planning. However, consistent implementation of the SDGs requires incorporation of all socially oriented priorities into development strategies.

Analysis of tasks and measures for the implementation of the SDGs provided in national conceptual and strategic documents demonstrates that there is a room for further increase of effectiveness of the implementation based on a contingent approach ensuring solidarity and balancing of social, economic and ecological aspects. The most suitable option is adoption of a complex development strategy including both national priorities and sectoral tasks. However, in the absence of political will for adoption and realization of a special implementation strategy, the following measures contribute to a solution: paying special attention to the SDGs while drafting policies and ensuring division of responsibilities among federal and regional executive bodies; specification of indicators for monitoring; regular monitoring based on specified indicators; involvement of social stakeholders in the realization, monitoring and evaluation; and heavy coverage of achieved results.

\section{References}

Bobylev S., Grigorev L. (2016) Celi ustojchivogo razvitija OON i Rossija. Doklad o chelovecheskom razvitii v Rossijskoj Federacii [The UN Sustainable Development Goals and Russia. Human Development Report in the Russian Federation]. Available at: http://ac.gov.ru/files/publication/a/11068.pdf (accessed 5 March 2018).

Bobylev S., Solov'ev S. (2017) Celi ustojchivogo razvitija dlja buduwego Rossii [Sustainable Development Goals for Russia's Future]. Available at: https://cyberleninka.ru/article/n/tseli-ustoychivogo-razvitiyadlya-buduschego-rossii: https://cyberleninka.ru/article/n/tseli-ustoychivogo-razvitiya-dlya-buduschego-rossii (accessed 10 March 2018).

Dunaev O., Nagornov V. (2017) Garmonizacija praktiki korporativnoj social'noj otvetstvennosti dlja dostizhenija celej ustojchivogo razvitija [Harmonization of corporate social responsibility practices to achieve sustainable development goals]. Gosudarstvenno-chastnoe partnerstvo, no 2. Available at: https:// cyberleninka.ru/article/n/garmonizatsiya-praktiki-korporativnoy-sotsialnoy-otvetstvennosti-dlyadostizheniya-tseley-ustoychivogo-razvitiya (accessed 1 March 2018).

Grigorev L., Pavlushina V. (2017) Social'noe neravenstvo kak problema jekonomicheskoj strategii Rossii [Social inequality as a problem of Russia's economic strategy]. Mir novoj economiki, no 3. Available at: https://cyberleninka.ru/article/n/sotsialnoe-neravenstvo-kak-problema-ekonomicheskoy-strategiirossii (accessed 5 March 2018).

Ryazanova N. (2018) Celi ustojchivogo razvitija OON i modernizacija professional'nogo jekologicheskogo obrazovanija: praktiko-orientirovannyj podhod [UN Sustainable Development Goals and Modernization of Environmental Professional Education: A Practice-Oriented Approach]. Available at: https:// cyberleninka.ru/article/n/tseli-ustoychivogo-razvitiya-oon-i-modernizatsiya-professionalnogo-ekologicheskogo-obrazovaniya-praktiko-orientirovannyy-podhod (accessed 6 March 2018). 
Sachs J., Schmidt-Traub G., Kroll C., Durand-Delacre D., Teksoz K. (2017) SDG Index and Dashboards Report 2017. Available at: http://www.sdgindex.org/assets/files/2017/2017-SDG-Index-andDashboards-Report--full.pdf (accessed 1 March 2018).

Sudas L. (2017) Biznes za ustojchivoe razvitie [Business for sustainable development]. Gosudarstvennoe upravlenie. Jelektronnyj vestnik, no 64. Available at: https://cyberleninka.ru/article/n/biznes-za-ustoychivoe-razvitie (accessed 6 March 2018).

UN Sustainable Development Solutions Network (SDSN) (c. a.) Official web-site. Available at: http:// unsdsn.org/ (accessed 11 December 2018).

UNDP (2017) Human Development Reports. Gender Inequality Index. Available at: http://hdr.undp. org/en/composite/GII (accessed 1 March 2018). 


\title{
Перспективы реализации Целей устойчивого развития ООН в России ${ }^{1}$
}

\author{
А.Г. Сахаров, О.И. Колмар
}

Сахаров Андрей Геннадиевич - н.с. Центра исследований международных институтов Российской академии народного хозяйства и государственной службы при Президенте РФ (РАНХиГС); Российская Федерация, 119034, Москва, Пречистенская наб., д. 11; E-mail: sakharov-ag@ranepa.ru

Колмар Ольга Ивановна - н.с. Центра исследований международных институтов (ЦИМИ) Российской академии народного хозяйства и государственной службы при Президенте РФ (РАНХиГС); Российская Федерация, 119034, Москва, Пречистенская наб., 11; E-mail: kolmar-oi@ranepa.ru

Цели устойчивого развития, принятые Генеральной Ассамблеей ООН 25 сентября 2015 г. в рамках Резолюции 70/1 «Преобразование нашего мира: Повестка дня в области устойчивого развития на период до 2030 года», охватывают широкий спектр проблем, с которыми сталкиваются как развивающиеся, так и развитые страны.

Проблематика достижения ЦУР актуальна и для международной повестки дня, и в связи с задачами соииально-экономического развития Российской Федерации. Поэтому приобретает особую важность выявление приоритетных для России направлений устойчивого развития в среднесрочной перспективе. Анализ в рамках данной статьи построен на соотнесении приоритетов, заявленных в Указе Президента РФ «О национальных целях и стратегических задачах развития Российской Федерации на период до 2024 года» (Майский указ-2018), а также в действующих Государственных программах РФ, и конкретных задач ЦУР. Основная цель работы выявить, насколько полно и системно задачи ЦУР реализуются в стратегических документах, определяющих основные направления развития России на кратко- и среднесрочную перспективу.

Проведенная авторами статьи работа показывает, что есть существенный ресурс повышения эффективности достижения ЦУР на основе реализации комплексного подхода, обеспечивающего единство и сбалансированность социальных, экономических и экологических аспектов устойчивого развития. Так, существует необходимость повышения уровня системности в подходе нашей страны к реализации ЦУР, в частности более полного включения социальных аспектов устойчивого развития в национальные документы стратегического планирования.

Ключевые слова: Цели устойчивого развития (ЦУР); устойчивое развитие; Повестка 2030; Социальноэкономическое развитие Российской Федерации; Майский указ 2018 г.; Госпрограммы Российской Федерации

Для цитирования: Сахаров А.Г., Колмар О.И. (2019) Перспективы реализации Целей устойчивого развития ООН в России // Вестник международных организаций. Т. 14. № 1. С. 189-206 (на русском и английском языках). DOI: 10.17323/1996-7845-2019-01-11

\section{Источники}

Бобылев С.Н., Григорьев Л.М. (2016) Цели устойчивого развития ООН и Россия: доклад о человеческом развитии в Российской Федерации. Режим доступа: http://ac.gov.ru/files/publication/a/11068.pdf (дата обращения: 05.03.2018).

${ }^{1}$ Статья поступила в редакцию в сентябре 2018 г.

Исследование выполнено в рамках научно-исследовательской работы государственного задания РАНХиГС «Стратегии ведущих стран-доноров помощи развитию по достижению Целей устойчивого развития» (2018 г.). 
Бобылев С.Н., Соловьева С.В. (2017) Цели устойчивого развития для будущего России // Проблемы прогнозирования. № 3. Режим доступа: https://cyberleninka.ru/article/n/tseli-ustoychivogo-razvitiyadlya-buduschego-rossii: https://cyberleninka.ru/article/n/tseli-ustoychivogo-razvitiya-dlya-buduschegorossii (дата обращения: 10.03.2018).

Григорьев Л.М., Павлюшина В.А. (2017) Социальное неравенство как проблема экономической стратегии России // Мир новой экономики. № 3. Режим доступа: https://cyberleninka.ru/article/n/ sotsialnoe-neravenstvo-kak-problema-ekonomicheskoy-strategii-rossii (дата обращения: 05.03.2018).

Дунаев О.И., Нагорнов В.А. (2017) Гармонизация практики корпоративной социальной ответственности для достижения целей устойчивого развития // Государственно-частное партнерство. № 2. Режим доступа: https://cyberleninka.ru/article/n/garmonizatsiya-praktiki-korporativnoy-sotsialnoyotvetstvennosti-dlya-dostizheniya-tseley-ustoychivogo-razvitiya (дата обращения: 01.08.2018).

Послание Президента (2018) Послание Президента Российской Федерации Федеральному Собранию. 1 марта. Режим доступа: http://www.kremlin.ru/events/president/news/copy/56957 (дата обращения: 08.03.2018).

Правительство РФ (2010) Распоряжение Правительства РФ от 11 ноября 2010 г. N 1950-р о Перечне государственных программ. Режим доступа: http://pravo.gov.ru/proxy/ips/?docbody=\&nd=102142899 (дата обращения: 05.03.2018).

Правительство РФ (2018а) Постановление Правительства РФ от 31 октября 2018 года № 1288 «Об организации проектной деятельности в Правительстве Российской Федерации». Режим доступа: http://static.government.ru/media/files/gLitA0z6PBOIIreUV4AOA0v1otm15jdo.pdf (дата обращения: 01.09.2018).

Правительство РФ (2018б) Основные направления деятельности Правительства Российской Федерации до 2024 года, 29 сентября. Режим доступа: http://static.government.ru/media/files/ne0vGNJUk9SQj1GNNsXIX2d2CpCho9qS.pdf (дата обращения: 01.11.2018).

Рязанова Н.Е. (2018) Цели устойчивого развития ООН и модернизация профессионального экологического образования: практико-ориентированный подход // Знание. Понимание. Умение. № 2. Режим доступа: https://cyberleninka.ru/article/n/tseli-ustoychivogo-razvitiya-oon-i-modernizatsiya-professionalnogo-ekologicheskogo-obrazovaniya-praktiko-orientirovannyy-podhod (дата обращения: 06.10.2018).

Совет Федерации Федерального Собрания РФ (2016) Постановление Совета Федерации Федерального Собрания РФ от 2 марта 2016 г. № 95-СФ. Режим доступа: http://www.council.gov.ru/activity/documents/65224/ (дата обращения: 05.03.2018).

Судас Л.Г. (2017) Бизнес за устойчивое развитие // Государственное управление. Электронный вестник. № 64. Режим доступа: https://cyberleninka.ru/article/n/biznes-za-ustoychivoe-razvitie (дата обращения: 06.10.2018).

Указ Президента РФ (2018) О национальных целях и стратегических задачах развития Российской Федерации на период до 2024 года». Режим доступа: http://www.kremlin.ru/acts/bank/43027 (дата обращения: 05.03.2018).

Sachs J., Schmidt-Traub G., Kroll C., Durand-Delacre D., Teksoz K. (2017) SDG Index and Dashboards Report 2017. Режим доступа: http://www.sdgindex.org/assets/files/2017/2017-SDG-Index-and-DashboardsReport--full.pdf (дата обращения: 01.02.2018).

UN Sustainable Development Solutions Network (SDSN) (с. а.) Official web-site. Режим доступа: http:// unsdsn.org/ (дата обращения: 11.12.2018).

UNDP (2017) Human Development Reports. Gender Inequality Index. Режим доступа: http://hdr.undp. org/en/composite/GII (дата обращения: 01.08.2018). 